Uşak Üniversitesi Sosyal Bilimler Dergisi

$2014,7 / 3$

\title{
Eğitimde Kademeler Arası Geçişle İlgili Öğretmen Görüşlerinin İncelenmesi*
}

\author{
Erkan DİNÇ** \\ Ceyhun UZUN*** \\ Okan ÇOBAN ${ }^{* * * * * *}$
}

\begin{abstract}
Özet
Ülkemizde eğitim konusundaki reform çalışmaları kapsamında en son $4+4+4$ eğitim sistemi ve kademeler arası geçişte de TEOGS gibi uygulamalar başlatılmıştır. Bu çalışma, 2013-2014 eğitim-öğretim yılında Ankara ve Uşak illerinde görev yapan ilk ve ortaöğretim öğretmenlerinin mesleki rehberlik, yönlendirme, kademeler arası geçiş ve yeni ortaöğretime geçiş sistemi konularındaki düşüncelerini incelemek amacıyla gerçekleştirilmiş̧ir. Nicel araştırma yöntemlerine göre tasarlanan çalışmada Yurdakul (2009) tarafından hazırlanan anket formu yeniden düzenlenip geliştirilmiş ve veri toplama aracı olarak kullanılmıştır. Toplam 293 öğretmenden toplanan veriler betimsel olarak analiz edilerek yorumlanmıştır. Araştırma bulgularına göre öğretmenler okuldaki rehberlik hizmetlerinin yetersiz olduğunu bunun da rehber öğretmen eksikliğinden kaynaklandığına düşünmektedir. Bulgular ayrıca kademeler arası geçişte öğrencilerin sosyal ve psikolojik özellikleri ile ilgili formlar dikkate alınmadığını ve etkin kullanılmadığını göstermektedir. Katılımcıların büyük çoğunluğu kademeler arası geçişte mesleki yönlendirmenin ortaokulda başlaması gerektiğini ve TEOGS uygulamasını olumlu bulduklarını belirtmişlerdir. $4+4+4$ Sistemi ise altyapı yetersizliği, pilot uygulama yapılmadan sisteme geçilmesi, okula başlama yaşının düşürülmesi ve 5 . sınıfların ortaokula dâhil edilmesi gibi olumsuz yönleri nedeniyle katılımcılar tarafından faydalı bulunmamıştır.
\end{abstract}

\footnotetext{
* Bu çalışmanın bir bölümü 16-18 Ocak 2014 tarihleri arasında Atatürk Kültür, Dil ve Tarih Yüksek Kurumu Atatürk Araştırma Merkezi Başkanlığı ile Gazi Üniversitesi Gazi Eğitim Fakültesi tarafından Antalya' da düzenlenen Cumhuriyet'in Kuruluşundan Günümüze Ĕ̆itimde Kademeler Arası Geçiş ve Yeni Modeller Uluslararası Kongresi'ne "Kademeler Arası Geçiş Hakkında Öğretmen Görüşleri" adıyla sözlü bildiri olarak sunulmuş olup Bildiriler Kitabında basılmamıştır.

** Doç. Dr., Uşak Üniversitesi Eğitim Fakültesi, erkandinc@gmail.com

*** Doktora Öğrencisi, Öğretmen, Uşak MEM, ceyhun.uzun@hotmail.com

**** Doktora Öğrencisi, Öğretmen, Ankara MEM, ocoban06@gmail.com
} 
Anahtar Kelimeler: Eğitimde Kademeler Arası Geçiş, Rehberlik ve Mesleki Yönlendirme, Öğretmen Görüşleri.

\title{
An Investigation of Teachers View Points on the Transition between Various Schooling Levels
}

\begin{abstract}
4+4+4 Transition system and TEOGS (the Transition Examinations from Primary to Secondary Education) are the latest reforms included in the educational renevations in Turkey. This study aims to investigate the views of primary and secondary school teachers working in Ankara and Uşak in 2013-2014 academic year on guidance and vocational guidance, the transition between various schooling stages and TEOGS. Employing an improved version of the questionnaire first developed by Yurdakul (2009) as a data collection tool, this study designed as a quantitative survey research. The data collected from 293 teachers was descriptively analysed and interpreted. According to the study findings, the teachers think that the counselling and guidance services in Turkish schools are insufficient and this arise from the lack or limited number of counselling teachers in schools. Another finding indicate that the data collected by counselling and guidance services on students' social and psychological characteristics have not effectively been used by the relevant authorities. Besides, most participants hold that the vocational guidance services must start in middle school years. While the participants present positive attitudes on TEOGS, they express negative view points on the latest transition system $(4+4+4)$ between schooling levels. According to the participants the reasons behind those negative perspectives are insufficient substructure, the implementatiton of the system without piloting, the reduce of the students' school starting age and the inclusion of grade 5 in middle schools.
\end{abstract}

Key Words: The Transition between Various Schooling Levels, Counselling and Vocational Guidance, Teachers' View Points.

\section{Giriş}

Küreselleşen dünyada devamlı olarak sosyal, siyasal, ekonomik ve teknolojik değişimler yaşanmaktadır. Ülkeler bu değişimler karşısında kendilerini geliştirebilmek ve bu değişimlere ayak uydurabilmek için insan kaynaklarını da geliştirmek durumundadır. Çünkü ülkelerin gelişmişlik 
göstergelerinin en önemlilerinden biri sahip oldukları vasıflı insan gücü ve planlanmış insan kaynağıdır. Avrupa Birliği kapsamında rekabette ön sıralarda yer almanın ilk koşulu ise; nitelikli insan gücü ihtiyacına cevap verebilecek eğitim politikalarının izlenmesidir (Tarlakazan, 2013).

Yaşanan değişim, meslek standartlarını değiştirmekte ve meslek seçimlerini de etkilemektedir. İyi bir eğitim ve meslek seçimi, insanın tüm yaşamı boyunca başarılı, ülkesine faydalı ve mutlu bir şekilde hayat sürmesine etki eden temel faktördür. İyi bir eğitim ve meslek seçiminin temelinde mesleki yönlendirme yer almaktadır (Yılmaz, 2004). Bireyin yetenek ve ilgilerine uygun bir alana yönelerek buna uygun öğrenim görmesi, mesleğini bu doğrultuda seçmesi sadece kendini gerçekleştirerek mutlu olmasına değil; aynı zamanda insanlığın ve toplumların kültürel, sosyal, bilimsel, teknolojik ve ekonomik gelişimlerine ve refah düzeylerine de katkı sağlayacaktır.

Eğitim süreci boyunca okullarda yürütülen yönlendirme çalışmaları, eğitimsel yönlendirme ve mesleki yönlendirme olmak üzere iki gruba ayrılır. Özoğlu (1981: 94-95), eğitimsel sorunlarla ilgili olarak eğitim sisteminde bireye ve bireylere götürülen öğrenme yardımı etkinliklerini "eğitimsel yönlendirme", bireye mesleksel tercihler yapmasında, bir meslek alanına yönelmesinde, bu meslek alanı içinde bir meslek seçmesinde ve mesleğe hazırlanmasında götürülecek etkinlikleri içeren yönlendirme çalışmalarını ise "meslekî yönlendirme" olarak tanımlamaktadır. Eğitimsel ve mesleki yönlendirmenin ortak temel ilkesi bireyi tanımak, onun kendini tanımasına, yetenek, ilgi ve istekleri doğrultusunda başarıya ulaşmasına yardımcı olmaktır.

Ülkeler, vatandaşlarına iyi bir meslek seçimi şansı sağlamak için farklı ilgi, istek ve yeteneklere uygun eğitim program ve imkânları hazırlamaktadırlar. Eğitim programları bireysel potansiyelin çeşitli yönlerden birey ve toplum için en uygun şekilde geliştirilmesini amaçlamaktadır. Bu da çocukların ve gençlerin akademik başarıları, yetenekleri, ilgileri, kişilik özellikleri doğrultusunda çeşitli programlara yöneltilerek yetiştirilmeleriyle sağlanabilir. Öğrencilerin mesleki yeteneklerinin tespit edilip, kendilerine uygun alanlarda eğitim görmelerini sağlamak; başarılı bireyler yetiştirebilmenin gereklerindendir. Genel olarak yeteneklerin tespiti, çok karmaşık bir süreçtir. Bu sürecin iyi yönetilememesi veya yanlış yönetilmesiyle, öğrencilerin eğitim hayatında ve dolayısıyla yaşamları boyunca sıkıntılar ortaya çıkmaktadır. Yeteneklerin belirlenmesi için kullanılan klasik test yöntemlerinin birçok olumsuzluklar içerdiğini belirten Arı ve Vatansever (2009), modern teknikler kullanarak bu olumsuzlukların büyük oranda giderilebileceğine işaret etmişlerdir. 
Özoğlu, öğrencileri okul durumlarına ve eğitim programlarına yönlendirmede rehberlik uzmanının rolünü "her öğrenciye ait önemli bilgileri toplamak ve bilmek, okuldaki veya okullardaki farklı eğitim programlarını ve özelliklerini bilmek, farklı eğitim programlarını ve dersleri öğrencilere etkili bir biçimde tanıtmak ve mümkünse bilgi aktarma yerine daha etkili ve öğrencilerin aktif olarak katılacakları yöntemleri kullanmak ayrıca yeni öğrenciler için okuldaki diğer çalışanlarla beraber bir yönlendirme ve duruma hazırlama programı hazırlamak ve yürütmektir" (1981: 94-95) şeklinde açıklamıştır.

İlköğretim kurumlarında mesleki rehberlik ve mesleğe yönlendirme konusuyla ilgili yasal düzenlemelerde; "İlköğretim okulu son sinıf öğrencilerini mesleki ve teknik eğitime yöneltmek üzere; mesleki ve teknik örgün yaygın eğitim okul ve kurum müdürlüklerince bir program çerçevesinde okul gezileri düzenlenerek atölye ve laboratuvarların tanitılması, seminer, konferans ve sempozyumlar düzenlenerek mesleki ve teknik eğitim, insan gücü ve istihdam ilişkilerinin anlatılması, afiş, broşür, görsel ve işitsel eğitim araçlarıyla meslek alanlarının tanıtılması, öğrencilerin mesleki eğilimlerini saptamak üzere anket uygulanması ile yönlendirme çalışmaları yürütülür" ifadesi geçmektedir (MEB, 1999'den akt. Yılmaz, 2004: 9). Bu ifadenin günümüz ihtiyaçlarını karşılamasını beklemek mümkün görünmemektedir. Bununla birlikte Aşık'ın belirttiği gibi “Meslekî yönlendirme yalnız belli yaşlardaki öğrencilere belli yıllarda götürülen bir yardım olmamalıdır" (2008: 17) ilkesinden yola çıkılarak meslekî yönlendirme konusunda son yıllarda sıkça uygulanan mesleksel gelişme kavramı üzerinde durulmalıdır. Bu kavram, mesleğe yönelme, meslek seçimi, mesleğe giriş, mesleğe uyum, meslekte gelişme ve meslekte emekli oluşu kapsayan geniş bir kavramdır. Bu açıdan ele alındığında meslekî yönlendirme okul sürecini aşan, bireyin kariyer gelişimini izleyen bir hizmet yelpazesi olarak algılanmalıdır. Unutulmamalıdır ki ekonomileri güçlü ülkelerin dünyada söz sahibi olmaları, nitelikli insan gücünü yetiştirmede eğitimin özellikle de mesleki teknik eğitimin üstlendiği rolü 21. yüzyılın teknolojisi ile bütünleştirmesinden kaynaklanmaktadır (Uçar ve Özerbaş, 2013: 242).

Özoğlu'nun (1981: 96) Hamphreys, Traxler ve North' dan (1967) aktardığına göre araştırma bulgularının ışığında meslekî yönlendirmede üzerinde durulması gereken hususlar şunlardır:

Okul programları ve etkinlikleri içinde mesleksel gelişime önem vererek; 
a. Öğrencinin okul yaşamının erken yıllarında çalışmalar başlatılmalıdır.

b. Mesleğe yöneltme için sürekliliği olan bir program seçilmelidir.

c. Gelişme ve olgunlaşma vurgulanmalıdır.

d. Belirli bir mesleği zamanından önce seçme baskısından bireyi kurtarmaya çalışmalıdır.

e. Öğrencinin psikolojik ve sosyal özelliklerine ilişkin geniş ölçüde bilgi sahibi olunmalıdir.

f. Belirli bir meslek ya da iş yerine meslek seçme ve hazırlama konusu kariyer kavramı içinde ele alınmalıdır.

g. Öğretim, bireyin meslek seçmesi gibi kısıtlı bir iş ya da eylem için olmaktan çok mesleksel gelişim kavramı içinde ele alınmalıdır.

1739 sayılı Milli Eğitim Temel Kanununda da "İlgi, istidat ve kabiliyetleri doğrultusunda çeşitli programlara ve okullara yönlendirilecekleri ve millî eğitim sisteminin her bakımdan bu yönlendirmeyi gerçekleştirecek biçimde düzenleneceği"' belirtilmiştir. Aynı zamanda orta öğretimin amaç ve görevleri ile ilgili bölümde "öğrencileri, çeşitli program ve okullarla ilgi, istidat ve kabiliyetleri ölçüsünde ve doğrultusunda yükseköğretime veya hem mesleğe hem de yükseköğretime veya hayata ve iş alanlarına hazırlamak" ifadesine yer verilmektedir (MEB, 1973: 2-6). Buradan hareketle Milli Eğitim Bakanlığ 1 kademeler arası geçişte ilkokul ve ortaokulun türleri bulunmazken (imam-hatip ortaokulu hariç) lise için birçok tür bulunmaktadır; Argon ve Soysal'a (2012: 447-448) göre lise türü çeşitliliği öğrencilerde yönlendirme olmadığı durumda tercih karışıklığına neden olabileceği gibi, gelecek kaygısı ön plana çıkaran toplumsal bakış açısıyla da daha nitelikli eğitim verdiği kabul edilen fen ve anadolu öğretmen liselerine olan talebi artırmaktadır. Diğer yandan ortaöğretime girişte sinavlar konusunda sürekliliği olan bir sistem uygulamaya konulamamış, bu durum beraberinde pek çok sorunu da getirmiştir. Ortaöğretime girişte ilköğretim ikinci kademede (bugünkü adıyla ortaokulda) son yıllarda değişik isimlerde ve farklı şekillerde pek çok sınavın uygulamaya konulması bu duruma örnek olarak verilebilir. En son sistem ise bu yıl uygulamaya konan Temel Eğitimden Ortaöğretime Geçiş Sistemi'dir (TEOGS). Bu sisteme göre öğrenciler 6 dersten ortak sinavlara girecekler ve her dönemde bu sinavlar tekrar edilecek. Öğrenciler ilgili derslerin yazılı sınavlarına girmiş olacaklar aynı zamanda da istedikleri ortaöğretim kurumuna yerleşmenin kapısını aralamış olacaklardır.

Bilindiği üzere, eğitim bir sistemdir ve okul öncesi eğitim, ilköğretim, ortaöğretim, yükseköğretim ve lisansüstü öğretim, eğitim sistemini oluşturan basamaklardır. Bir eğitim sistemini oluşturan basamaklardaki bir 
sorun kaçınılmaz olarak sistemin tamamını da olumsuz biçimde etkileyecektir (Arslan, 2004: 42). Bu noktadan hareketle kademeler arası geçişe etki edebilecek faktörlerin veya sorunların sistemin uygulayıcısı olan öğretmenlerin izlenim, görüş ve önerileri doğrultusunda belirlenmesi öne arz etmektedir. Üst kademelerdeki sorunları önleme adına sistemdeki sıkıntılı noktaların detaylarıyla ve gerekçeleriyle tespiti, etki ve sonucu çok sonra elde edilebilecek olan uygulamalara ışık tutacaktır. Ayrıca mesleki rehberlik alanında okulda verilen hizmetler hakkında öğretmenlerin görüşleri ve sorunların tespitlerine yönelik değerlendirmeleri gittikçe önem kazanan mesleki eğitimin planlanmasına katkı sunacaktır. $4+4+4$ eğitim sisteminde ve yeni orta öğretime geçiş sisteminde belli birtakım avantajlar ve dezavantajlar göze çarpmaktadır. Ancak bu durumların öğretmenlerimizin bakış açısıyla yorumlanmaları doğrudan karşılaşılan problemlerin ve olumlu yönlerin neler olduğunu net olarak tanımlanabilmesini ve çözümler üretilebilmesini olanaklı kılacaktır.

\subsection{Problem Durumu}

Meslek seçiminde yapılan araştırmalarda meslek seçiminin başlayacağı eğitim kademesi konusunda farklı görüşlerden bahsedilmektedir. Öte yandan ülkemizde 2012-2013 eğitim öğretim yılında uygulamaya konulan $4+4+4$ eğitim sistemi ile kademeler arası geçişte yeni bir döneme geçilmiştir bununla birlikte 2013-2014 eğitim öğretim yılında liselere girişte TEOGS adı altında yeni bir sınav sistemi uygulamaya konulmuştur. Eğitim sistemimizde mevcut olan kademeler arası geçiş ve sistemin en önemli unsurlarından biri olan yönlendirmenin sorunları araştırılarak ortaya çıkartılmalıdır. Elde edilecek olan bu sorunlar ve bu sorunlara neden olan faktörlerin de sorgulanması gerekmektedir. Yönlendirmenin ve kademeler arası geçişin tam ve eksiksiz olarak nasıl uygulanması gerektiği de belirlenmelidir.

\section{2. İlgili Çalışmalar}

Arslan'ın 2004 tarihli tarama çalışması eğitim kademeleri arası geçişte öğrencilerin okul başarılarının yanında ilgi ve yeteneklerinin belirleyici olması gerektiği, bunun için de okullarımızda rehberlik hizmetlerinin tam olarak sağlanmasının önemi ortaya konulmuştur. Mesleki ve teknik eğitimin ele alan çalışmasında Doğan, (1997) etkili bir mesleki eğitim için yöresel finansal kaynakların işe koşulmasını, iş dünyası ile ortak çalışma esasına dayalı anlamlı birliktelikler kurulmasını, uluslararası standartlar ışığında mesleki becerilerin yeniden ele alınmasını, mesleki 
beceriler edinmede geniş tabanlı bilgi ve becerilere yer verilmesini ve öğretmen yetiştirme politikalarının da bu doğrultuda yeniden gözden geçirilmesini çeşitli kanıtlara dayalı olarak ortaya koymuştur.

Argon ve Soysal, 2012 yılında yaptıkları nitel araştırmada SBS sınavının stres, korku, heyecan, merak gibi duygular uyandırıp, öğrencilerin gelecekteki eğitim hayatı ve mesleğini belirlemede oldukça önemli etkiye sahip olduğu ortaya koymuşlardır. Bu çalışmada ayrıca SBS sınavının öğrencilerin sosyalleşmelerini engellediği, sınavın kapsamı ile okulda işlenen dersler arasında uyumsuzluk olduğu, öğrencilerin merkezi sınavlara hazırlanmak amacıyla özel ders, dershane vb. gibi alternatiflere yönlendirildiği ve okul yöneticilerinin sınav sonuçlarına aşırı önem verdiği gibi sonuçlara ulaşılmıştır. Çalışma katılımcıları, SBS yerine yetenek ve ilgilere göre seçim yapan, öğrenci-öğretmen-veli işbirliğine dayalı uygulamalar konusunda önerilerde bulunmuşlardır.

Karadeniz'in, (2012) çalışması, öğretmenlerin \%80'inin $4+4+4$ sisteminin yeterince tartışılmadan uygulamaya konulduğu, \%30'unun bu sisteme koşulsuz destek verdiğini; \%53'ünün zorunlu eğitimin 12 yıla çıkmasını olumlu bulduğu sonuçlarını ortaya çıkarmıştır. Ayrıca, okula erken başlamanın sakıncalı olduğunu (\%77) belirten araştırma katılımcıları, kişilikleri gelişmeyen çocukların farklı eğitim programlarına yönlendirilmesinin sakıncalı olacağını (\%60) belirtmişlerdir.

Memişoğlu ve İsmetoğlu'nun 2013 tarihli nitel çalışmalarının sonucuna göre okul yöneticileri uygulamanın kesintili olmasını doğru bulmuşlar, ancak bu kesintilerin $5+3+4$ şeklinde düzenlenerek okula başlama yaşının da 72 aya çekilmesi gerektiğini önermişlerdir. Uygulamayı olumsuz olarak değerlendiren katılımcılar; ortaokul kademesinde bireylerin farklı ilgi alanlarına göre eğitilmesinin doğru fakat uygulamanın sadece İmam Hatip Liseleri ile sınırlandırılmış olmasını eksik gördüklerini ifade etmişledir.

Külekçi'nin, (2013) çalışmasında ise birleştirilmiş sınıfta eğitim veren 12 sınıf öğretmenine ulaşmıştır. Araştırma sonuçlarına göre $4+4+4$ kesintili zorunlu eğitim sisteminin birleştirilmiş sınıflarda öğrenci sayısının azalmasına bağlı olarak az da olsa olumlu katkısı olduğu ama okula başlama yaşının düşürülmesi ve fiziki altyapının yetersizliği gibi sorunların öğretmenlerin iş yükünü arttırdığı sonuçlarına ulaşılmıştır.

Konu ile ilgili yapılan çalışmalarda, kademeler arası geçişi bazı boyutları ile ele alınmış ancak okullardaki rehberlik hizmetlerinin durum ve işlevleri ile uygulamadaki sınav sistemi olan TEOGS'a değinilmemiştir. Bu araştırma okullardaki rehberlik ve yönlendirme hizmetlerinin durumu ile TEOGS hakkındaki öğretmen görüşlerinin tespit etme amacı dolayısıyla ilgili alan yazına katkı sağlama potansiyeline sahiptir. 


\section{Yöntem}

İlk ve ortaöğretimde görev yapan öğretmenlerin kademeler arası geçiş ve yönlendirmeye ilişkin tespit, görüş ve önerilerini belirlemeyi amaçlayan bu araştırma, tanımlayıcı nitelikte bir durum saptama çalışmasıdır. Tarama modelinde bir durum saptama çalışması olan bu araştırma katılımcıların kademeler arası geçiş ve yönlendirmeye ilişkin tespit, görüş ve önerilerini olduğu şekliyle betimlemeyi amaçlamaktadır. Bu kapsamda aşağıdaki sorulara cevap aranmıştır.

- Öğretmenlerin okullardaki rehberlik ve yönlendirme hizmetlerini nasıl bulmaktadır?

- Okullardaki mesleki rehberlik ve yönlendirme çalışmalarının hangi ölçüde etkili ol maktadır?

- Öğrencilere yönelik rehberlik ve yönlendirme hizmetlerinde onların sosyal ve psikolojik özellikleri ne ölçüde dikkate alınmaktadır?

- Yönlendirme ve kademeler arası geçiş hakkında öğretmenlerin düşünceleri nelerdir?

- Öğretmenlerin yeni sınav sistemi ile ilgili düşünce ve önerileri nelerdir?

\subsection{Veri Toplama Aracı, Çalışma Grubu ve Verilerin Toplanması}

Çalışmada veri toplama aracı olarak araştırmacılar tarafından hazırlanan bir anket formu kullanılmıştır. Veri toplama aracı hazırlanırken Yurdakul' un (2009) çalışmasında katılımcılara sorulan sorular incelenmiş ve kendisinin izniyle bunların bir kısmı doğrudan bir kısmı da uyarlanarak kullanılmıştır. Ayrıca, bunlara ilave olarak yukarıda sunulan araştırma amaçları doğrultusunda ikisi açı uçlu olmak üzere yeni maddeler hazırlanmış uzman görüşü alındıktan sonra veri toplama aracına son şekli verilmiştir.

Araştırmanın çalışma grubu, amaçlı örnekleme yöntemlerinden kolay ulaşılabilir durum örneklemesiyle belirlenmiştir. Bu çerçevede Ankara ve Uşak illerinde görev yapan ve araştırma ekibi tarafından ulaşılabilecek olan öğretmenler çalışma grubuna dâhil edilmiştir. Çeşitli eğitim kademeleri ve okul türlerinden toplam 284 öğretmene ulaşılmıştır.

\subsection{Verilerin Analizi}

Araştırmanın nicel verilerinin analizinde frekans analizi ve ki-kare testi uygulanmıştır. Bu amaçla SPSS 20.0 paket programı kullanılmış, elde 
edilen bulgular tablolar halinde sunulup yorumlanmıştır. Ayrıca ankete dâhil edilen yarı-yapılandırılmış açık uçlu sorulardan elde edilen veriler betimsel olarak analiz edilmiştir.

\section{Bulgular}

Araştırmanın demografik verileri aşağıdaki tabloda sunulmuştur.

Tablo 1: Araştırmadaki Çalışma Grubunun Demografik Özellikleri

\begin{tabular}{|c|c|c|c|}
\hline İfade & Cevaplar & $f$ & $\%$ \\
\hline \multirow{2}{*}{ Cinsiyet } & Bay & 113 & 39.8 \\
\hline & Bayan & 171 & 60.2 \\
\hline \multirow{2}{*}{ Branş } & Sınıf Öğretmeni & 102 & 35.9 \\
\hline & Branş Öğretmeni & 182 & 64.1 \\
\hline \multirow{4}{*}{ Çalışılan okulun türü } & İlkokul & 113 & 39.8 \\
\hline & Ortaokul & 113 & 39.8 \\
\hline & Anadolu Lisesi & 47 & 16.5 \\
\hline & Meslek Lisesi & 10 & 3.5 \\
\hline \multirow{5}{*}{$\begin{array}{l}\text { Okuldaki rehberlik } \\
\text { öğretmeni sayısı }\end{array}$} & Öğretmen yok & 75 & 26.4 \\
\hline & 1 öğretmen & 115 & 40.5 \\
\hline & 2 öğretmen & 35 & 12.3 \\
\hline & 3 öğretmen & 54 & 19.0 \\
\hline & 4 öğretmen & 5 & 1.8 \\
\hline \multirow{6}{*}{ Kıdem yılı } & $0-5 Y_{11}$ & 65 & 22.9 \\
\hline & 6-10 Y1l & 66 & 23.1 \\
\hline & 11-15 Yil & 77 & 27.1 \\
\hline & $16-20 Y_{11}$ & 45 & 16 \\
\hline & 20 Yıl ve Üzeri & 31 & 10.9 \\
\hline & Toplam & 284 & 100 \\
\hline
\end{tabular}

Araştırmaya katılan öğretmenlerin \%60.2'si bayan ve \%39.8'i erkektir. Bununla birlikte araştırmada sınıf öğretmenlerinin katılım payı \%35.9 oranla 102 kişi ve branş öğretmenlerinin katılım payı ise \%64.1 oranla 182 kişi olmuştur. Araştırmadaki öğretmenlerin \%39.8'i ilk okul ve ortaokul; \%16.5'i Anadolu lisesinde, \%3.5'si meslek lisesinde çalışmaktadır. Okuldaki rehber öğretmen sayısına bakıldığında rehber öğretmen olmayan okul oranı \%26.4; 1 rehber öğretmen bulunan okul oranı \%40.5; 2 rehber bulunan okul oranı \%12.3; 3 rehber öğretmen bulunan okul oranı \%19; 4 rehber öğretmen bulunan okul oranı \%1.8'dir. Araştırmaya katılan öğretmenlerin kıdem yılına bakıldığında 0-5 yıl arası kıdeme sahip olan öğretmenler toplam 
sayının \%22.9'unu; 6-10 yıl arası olanlar \%23.1'ni; 11-15 yıl arasındakiler \%27.1'ni; 16-20 yıl arası kıdemde bulunan öğretmenler \%16'sını ve 20 yıl üzerindekiler \%10.9'ni oluşturmaktadır. Çok fazla veriye ulaşılması nedeniyle çalışma kapsamında ulaşılan diğer verilerin analiz ve değerlendirmesinde demografik verilerden yalnızca okuldaki rehberlik öğretmeni sayısı kullanılmıştır.

Araştırmada ulaşılan veriler 5 ana boyutta toplanmıştır. Araştırmanın alt boyutları aşağıda sıralanmıştır;

1. Rehberlik ve Yönlendirme Boyutu

2. Mesleki Rehberlik Boyutu

3. Psikolojik ve Sosyal Özellikler Boyutu

4. Öğrencileri Yöneltme ve Kademeler Arası Geçiş Boyutu

5. Yeni Sinav Sistemi Boyutu

$\mathrm{Bu} 5$ boyutla ilgili ulaşılan veriler aşağıda analiz edilmiştir.

\subsection{Rehberlik ve Yönlendirme Boyutu}

Tablo 2: Rehberlik ve Yönlendirme Hizmetlerinin ve Öğretmenlerin Rehberlik Görevlerini Yerine Getirme Konusundaki Düşünceleri İle İlgili Frekans Dağılımı

\begin{tabular}{|c|c|c|c|}
\hline İfade & Cevaplar & $f$ & $\%$ \\
\hline \multirow{3}{*}{$\begin{array}{l}\text { Okuldaki rehberlik ve yönlendirme } \\
\text { hizmetlerini yeterliliği }\end{array}$} & Evet & 88 & 31.0 \\
\hline & Kismen & 97 & 34.2 \\
\hline & Hayır & 99 & 34.9 \\
\hline \multirow{3}{*}{$\begin{array}{l}\text { Okuldaki öğretmenlerin rehberlik } \\
\text { görevlerini tam olarak yerine } \\
\text { getirmeleri konusundaki düşünceler }\end{array}$} & Evet & 85 & 29.9 \\
\hline & Kismen & 150 & 52.8 \\
\hline & Hayır & 47 & 16.5 \\
\hline
\end{tabular}

Rehberlik ve yönlendirme boyutu ile ilgili öğretmenlere sorulan sorular yukarıdaki gibidir. Çarpıcı sonuç ise katılımcıların öğretmenlerin rehberlik görevlerini yerine getirmediğini düşünmeleridir. Buna göre öğretmenlerin \%69.1'i okuldaki rehberlik ve yönlendirme hizmetlerini kısmen yeterli veya yetersiz bulmaları dolayısıyla da bu hizmetlerin layıkıyla yerine getirilmediğini belirtmişlerdir. Bununla birlikte öğretmenlere; "öğretmenlerin rehberlik görevlerini tam olarak yerine getirdiğini düşünüyor musunuz?" sorusu sorulduğunda öğretmenlerin \%69.3'ünün yine kısmen yeterli veya yetersiz cevabını verdiğ 
görülmektedir. Rehberlik hizmetlerinin yetersiz bulunma sebepleri sorulduğunda ise aşağıdaki verilere ulaşılmıştır.

Tablo 3: Rehberlik Hizmetlerinin Yetersiz Bulunma Sebepleri Frekans Dağılımı

\begin{tabular}{lc}
\hline İfadeler & $f$ \\
\hline Rehber öğretmenin sayıca yetersizliği & 100 \\
\hline $\begin{array}{l}\text { Rehberlik ve yönlendirme hizmetlerine ilişkin ders saatinin } \\
\text { yetersizliği }\end{array}$ & 53 \\
\hline Diğer öğretmenlerle işbirliği ve koordinasyon yetersizliği & 42 \\
\hline Rehber öğretmenin kişisel-sosyal, mesleki açıdan yetersizliği & 27 \\
\hline Okul yönetiminin desteğinin yetersizliği & 25 \\
\hline Öğrencilerin Rehberlik Hizmetlerine olan ilgisizliği & 12 \\
\hline Öğretmenlerin ön yargılı bakış açısı & 11 \\
\hline
\end{tabular}

Tablo 3'e göre öğretmenlerin büyük çoğunluğu rehberlik hizmetlerini yetersizliğinin en önemli nedeni olarak rehberlik öğretmeni sayısının eksikliğinden bahsettikleri anlaşılmaktadır $(f=100)$. Katılımcıların dile getirdiği diğer önemli gerekçeler ise rehberlik ve yönlendirme hizmetlerine ayrılan sürenin yetersizliği ve rehberlik öğretmenleri ile diğer öğretmenler arasındaki işbirliği ve koordinasyon eksikliğidir.

Ayrıca "Okulunuzdaki rehberlik ve yönlendirme hizmetlerini yeterli buluyor musunuz?" ve "Okulunuzdaki öğretmenlerin rehberlik görevlerini tam olarak yerine getirdiklerini düşünüyor musunuz?" ifadelerine ilişkin okulda bulunan rehber öğretmenlerin sayısı değişkenine göre yapılan kikare testi sonuçları aşağıdaki gibidir. 
Tablo 4: Okuldaki Rehberlik Hizmetlerini Yeterli Bulmayan Öğretmenlerin Okul Rehber Öğretmen Sayısına Göre Dağılımı İle İlgili Ki-Kare Testi Sonuçları

\begin{tabular}{|c|c|c|c|c|c|c|c|c|}
\hline İfade & Değişken & & & & & & & $\begin{array}{l}\text { Ki- } \\
\text { kare }\end{array}$ \\
\hline \multirow{7}{*}{$\begin{array}{l}\text { Okuldaki } \\
\text { rehberlik ve } \\
\text { yönlendirme } \\
\text { hizmetlerini } \\
\text { yeterli } \\
\text { bulma } \\
\text { durumu }\end{array}$} & \multirow[b]{3}{*}{ Yok } & \multicolumn{2}{|c|}{ Evet } & \multicolumn{2}{|c|}{ Kismen } & \multicolumn{2}{|c|}{ Hayır } & \multirow{7}{*}{.00} \\
\hline & & $f$ & $\%$ & $f$ & $\%$ & $f$ & $\%$ & \\
\hline & & 0 & 0 & 17 & 18 & 58 & 59 & \\
\hline & 1 öğrt. & 42 & 48 & 40 & 41 & 33 & 33 & \\
\hline & 2 öğrt. & 17 & 19 & 15 & 16 & 3 & 3 & \\
\hline & 3 öğrt. & 26 & 30 & 23 & 24 & 5 & 5 & \\
\hline & 4 öğrt. & 3 & 3 & 2 & 2 & 0 & 0 & \\
\hline
\end{tabular}

Yukarıdaki tabloda da görüldügü üzere "Okulunuzdaki rehberlik ve yönlendirme hizmetlerini yeterli buluyor musunuz?" ifadesi ile okuldaki rehber öğretmen sayısına ilişkin yapılan ki-kare testi sonucunda anlamlı bir ilişki olduğu görülmektedir $(p<.01)$. Buna göre okuldaki rehberlik öğretmeni sayısı arttıkça sunulan rehberlik hizmetlerinin yeterliliğinin de artmaktadır.

Tablo 5: Rehberlik Öğretmenlerinin Görevlerini Tam Olarak Yerine Getirmeleri ile Okuldaki Rehberlik Öğretmen Sayısı Arasındaki Bağlantı İle İlgili Ki-Kare Testi

\begin{tabular}{|c|c|c|c|c|c|c|c|c|}
\hline İfade & Değişken & & & & & & & $\begin{array}{l}\text { Ki- } \\
\text { kare }\end{array}$ \\
\hline \multirow{7}{*}{$\begin{array}{l}\text { Okuldaki } \\
\text { öğretmenlerin } \\
\text { rehberlik } \\
\text { görevlerini } \\
\text { tam olarak } \\
\text { yerine getirip } \\
\text { getirmeme } \\
\text { konusundaki } \\
\text { düsünceleri }\end{array}$} & & \multicolumn{2}{|c|}{ Evet } & \multicolumn{2}{|c|}{ Kismen } & \multicolumn{2}{|c|}{ Hayır } & \\
\hline & & $f$ & $\%$ & $f$ & $\%$ & $f$ & $\%$ & \\
\hline & Yok & 13 & 15 & 43 & 29 & 17 & 36 & \\
\hline & 1 öğrt. & 38 & 44 & 65 & 43 & 12 & 26 & \\
\hline & 2 öğrt. & 16 & 19 & 15 & 10 & 4 & 9 & .07 \\
\hline & 3 öğrt. & 17 & 20 & 23 & 15 & 14 & 30 & \\
\hline & 4 öğrt. & 1 & 1 & 4 & 3 & 0 & 0 & \\
\hline
\end{tabular}

Yukarıdaki tabloda da görüldüğü üzere "Okulunuzdaki öğretmenlerin rehberlik görevlerini tam olarak yerine getirip getirmeme konusundaki düşünceleri ifadesi ile okuldaki rehber öğretmen sayısına 
ilişkin yapılan ki-kare testi sonucunda anlamlı bir ilişki olmadığı görülmektedir ( $p>05$ ). Yani araştırma katılımcıları okulda rehber öğretmen bulunup bulunmaması ve okuldaki rehber öğretmen sayısı ile öğretmenlerin rehberlik görevlerini yerine getirmeleri arasında doğrudan bir ilişki bulunmadığını düşünmektedir.

\subsection{Mesleki Rehberlik Boyutu}

Tablo 6: Mesleki Rehberlik ve Yönlendirme Konusundaki Çalışmaların Yeterliliği

\begin{tabular}{|c|c|c|c|}
\hline İfade & Cevaplar & $f$ & $\%$ \\
\hline \multirow{3}{*}{$\begin{array}{l}\text { Okuldaki mesleki rehberlik ve } \\
\text { yönlendirme ile ilgili yapılan } \\
\text { çalışmaları yeterli bulma durumu }\end{array}$} & Evet & 60 & 21.1 \\
\hline & Kismen & 138 & 48.6 \\
\hline & Hayır & 85 & 29.9 \\
\hline \multirow{3}{*}{ 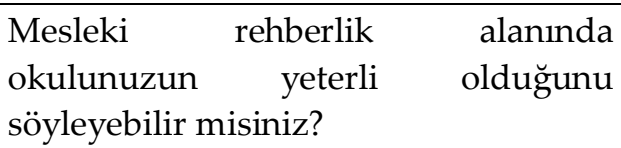 } & Evet & 49 & 17.3 \\
\hline & Kismen & 156 & 54.9 \\
\hline & Hayır & 79 & 27.8 \\
\hline
\end{tabular}

Mesleki rehberlik ve yönlendirme boyutuyla ilgili sorulan sorular aracıllğ 1 ile öğretmenlerin \%78,5'nin mesleki yönlendirme ve rehberlik hizmetlerini kısmen yeterli veya yetersiz bulduğu, \%82,7'sinin ise mesleki rehberlik alanında okullarını kısmen yeterli veya yetersiz bulduğu belirlenmiştir. $\mathrm{Bu}$ verilere göre okullarımız ve buralarda gerçekleştirilen mesleki rehberlik ve yönlendirme hizmetleri tam anlamıla amacına ulaşamamaktadır. Bu durumun nedenleri ile ilgili olarak ulaşılan veriler Tablo 7'de sunulmuştur.

Tablo 7: Öğretmenlerin Mesleki Rehberlik Hizmetlerini Yeterli Bulmama Nedenleri İle İlgili Frekans Dağılımı

\begin{tabular}{lc}
\hline İfadeler & $f$ \\
\hline Öğrencilerin ilgi alanlarının belirlenmesine yönelik eksiklikler & 66 \\
\hline $\begin{array}{l}\text { Öğrencilerin hobiler edinebilecek ya da sürdürebilecek fiziksel } \\
\text { koşulların yetersizliği }\end{array}$ & 65 \\
\hline $\begin{array}{l}\text { Ögrencilerin yetenek alanlarının belirlenmesine yönelik eksiklikler } \\
\text { Öğrencilerin yaş açısından ilgi ve yeteneklerinin ayrışmamış }\end{array}$ & 45 \\
\hline $\begin{array}{l}\text { Öğğrencilerin mesleki değer alanlarının belirlenmesine yönelik } \\
\text { eksiklikler }\end{array}$ & 37 \\
\hline
\end{tabular}


Öğretmenler rehberlik hizmetlerini yeterli bulmama nedenleri arasında en çok, öğrencilerin ilgi alanlarının belirlenmesine yönelik eksikliklere $(\mathrm{f}=66)$ ve öğrencilerin hobiler edinebilecek veya mevcut hobilerini sürdürebilecekleri fiziksel koşulların yetersizliğine vurgu yapmışlardır $(\mathrm{f}=65)$. Rehberlik edilecek öğrencilerin ilgi alanlarını belirlemeden onlara doğru ve uygun rehberlik hizmeti vermek mümkün değildir. Bununla birlikte öğrencilerin ilgi alanlarını keşfetmeleri için hobiler edinmeleri, bu hobileri devam ettirmeleri ve kendilerini keşfedecekleri ortamlarda eğitim yaşantılarında bulunmaları gerekmektedir. Çalışmaya katılan öğretmenler okulun yalnızca akademik faaliyetlere odaklanmasının yeterli ve amacına uygun rehberlik hizmetlerini sınırlandırdığını düşünmektedirler.

Ayrıca "Okulunuzda mesleki rehberlik ve yönlendirme ilgili yapılan çalışmaları yeterli buluyor musunuz?" ve "Mesleki rehberlik alanında okulunuzun yeterli olduğunu söyleyebilir misiniz?" sorularına verilen cevaplar ile okuldaki rehberlik öğretmeni sayısı arasındaki ilişkiyi belirlemek için yapılan ki-kare testi sonuçları aşağıdaki gibidir.

Tablo 8: Okuldaki Mesleki Rehberlik ve Yönlendirme İle İlgili Çalışmaların Yeterliliği ile Okuldaki Rehberlik Öğretmeni Sayısı Arasındaki İlişkiye Dair Ki-Kare Testi Sonuçları

\begin{tabular}{|c|c|c|c|c|c|c|c|c|}
\hline İfade & Değişken & & & & & & & $\begin{array}{l}\text { Ki- } \\
\text { kare }\end{array}$ \\
\hline \multirow{7}{*}{$\begin{array}{l}\text { Okuldaki } \\
\text { mesleki } \\
\text { rehberlik ve } \\
\text { yönlendirme } \\
\text { ile ilgili } \\
\text { yapılan } \\
\text { çalışmaları } \\
\text { yeterli } \\
\text { bulup } \\
\text { bulmama } \\
\text { durumu }\end{array}$} & \multirow[b]{3}{*}{ Yok } & \multicolumn{2}{|c|}{ Evet } & \multicolumn{2}{|c|}{ Kismen } & \multicolumn{2}{|c|}{ Hayır } & \\
\hline & & $f$ & $\%$ & $f$ & $\%$ & $f$ & $\%$ & \\
\hline & & 0 & 0 & 39 & 52 & 36 & 48 & \\
\hline & 1 öğrt. & 31 & 27 & 56 & 49 & 27 & 24 & \\
\hline & 2 öğrt. & 13 & 37 & 16 & 46 & 6 & 17 & .00 \\
\hline & 3 öğrt. & 15 & 28 & 23 & 43 & 16 & 30 & \\
\hline & 4 öğrt. & 1 & 20 & 4 & 80 & 0 & 0 & \\
\hline
\end{tabular}

Yukarıdaki tabloda da görüldüğü üzere, "Okulunuzda mesleki rehberlik ve yönlendirme ilgili yapılan çalışmaları yeterli buluyor 
musunuz?" ifadesi ile okuldaki rehber öğretmen sayısına ilişkin yapılan kikare sonucunda anlamlı bir ilişki olduğu görülmektedir $(p<.01)$. Bu verilere göre okulda rehberlik öğretmeni sayısı arttıkça katılımcıların rehberlik ve yönlendirme hizmetlerini yeterli bulma oranları da artmaktadır. Ayrıca öğretmenlere, mesleki anlamda rehberlik ve yönlendirmenin ne zaman yapılması gerektiğine ilişkin sorulan soru ışığında verilen cevaplar aşağıdaki gibidir.

Tablo 9: Mesleki Rehberlik ve Yönlendirmeye Eğitimin Hangi Safhasında Başlanması İle İlgili Görüşlerin Dağılımı

\begin{tabular}{lccc}
\hline İfade & Kademeler & $f$ & $\mathbf{\%}$ \\
\hline Mesleki rehberlik ve & Okul öncesi & 64 & 22.5 \\
\cline { 2 - 4 } yönlendirmeye başlama & İlkokul & 95 & 33.5 \\
\cline { 2 - 4 } dönemi ile ilgili görüşler & Ortaokul & 114 & $\mathbf{4 0 . 1}$ \\
\cline { 2 - 4 } & Lise & 5 & 1.8 \\
\hline
\end{tabular}

Yukarıdaki tabloya göre öğretmenlerin büyük bir çoğunluğunun $(\% 40,1)$ eğitimin ortaokul kademesinde mesleki rehberlik ve yönlendirmeye başlanması gerektiği cevabını verdiği görülmektedir. Açık uçlu sorularda bazı öğretmenler $4+4+4$ eğitim sisteminin mesleki yönlendirme için bir avantaj olabileceğini ve ortaokulda mesleki rehberlik ve yönlendirme çalışmalarının yapılmasının olumlu sonuçlar vereceğini düşündüklerini belirtmişlerdir. $\mathrm{Bu}$ da öğretmenlerin, yönlendirme faaliyetlerinin lise yıllarına bırakılmasını uygun bulmadıklarını göstermektedir. 


\subsection{Psikolojik ve Sosyal Özellikler Boyutu}

Tablo 10: Katılımcıların Öğrencilerin Psikolojik ve Sosyal Özelliklerine Yönelik Rehberlik ve Yönlendirme Faaliyetleri Konusundaki Görüşleri

\begin{tabular}{|c|c|c|c|}
\hline İfade & Cevaplar & $f$ & $\%$ \\
\hline \multirow{3}{*}{$\begin{array}{l}\text { Okulda öğrencilerin psikolojik ve } \\
\text { sosyal özelliklerine } \\
\text { toplama }\end{array}$} & Evet & 90 & 31.7 \\
\hline & Kismen & 134 & 47.2 \\
\hline & Hayır & 60 & 21.1 \\
\hline \multirow{3}{*}{$\begin{array}{l}\text { Okulda öğrencileri tanımaya yönelik } \\
\text { ölçme araçlarının kullanılıp } \\
\text { kullanılmaması }\end{array}$} & Evet & 96 & 33.8 \\
\hline & Kismen & 146 & 51.4 \\
\hline & Hayır & 42 & 14.8 \\
\hline \multirow{3}{*}{$\begin{array}{l}\text { Uygulanan } \begin{array}{c}\text { ölçme } \\
\text { sonucunda belirlenen }\end{array} \begin{array}{c}\text { araçları } \\
\text { ihtiyaçlar }\end{array} \\
\text { doğrultusunda } \\
\text { yaprekli çalışmaların yapılmaması }\end{array}$} & Evet & 63 & 22.2 \\
\hline & Kismen & 152 & 53.5 \\
\hline & Hayır & 68 & 23.9 \\
\hline \multirow{3}{*}{$\begin{array}{lcl}\text { Okulda öğrencilerle } & \text { ilgili olarak } \\
\text { velilerle } & \text { düzenli } & \text { görüşmelerin } \\
\text { yapılıp yapılmaması } & \\
\end{array}$} & Evet & 116 & 40.8 \\
\hline & Kismen & 133 & 46.8 \\
\hline & Hayır & 35 & 12.3 \\
\hline \multirow{3}{*}{$\begin{array}{llr}\text { Yönlendirme } & \text { formlarının } & \text { branş } \\
\text { öğretmenleri } & \text { tarafından } & \text { özenle } \\
\text { doldurulup doldurulmaması } & \end{array}$} & Evet & 91 & 32.0 \\
\hline & Kismen & 137 & 48.2 \\
\hline & Hayır & 54 & 19.0 \\
\hline
\end{tabular}

Öğrencilerin psikolojik ve sosyal özelliklerine dair veri toplanması, bu verilerin toplanma süreci ve toplanan verilerin kullanılması ile ilgili ifadelere öğretmenlerin verdiği cevaplara bakıldığında kısmen seçeneğini işaretleyenlerin fazlalığı göze çarpmaktadır. Dolayısıyla, belirtilen süreçlerde yeterli ve nitelikli bilgi toplanamadığı ve toplanan verilerin de amacına uygun olarak kullanılmadığı anlaşılmaktadır. Buna göre, rehberlik ve yönlendirme hizmetlerinde öğrencilerin psikolojik ve sosyal özelliklerinin göz ardı edilmesi ve sadece akademik başarı odaklı yönlendirmenin yapılması öğrencilerin ilerleyen yıllarda meslek seçimi sorunları ve istediğ mesleği yapamama gibi problemlerle karşılaşma ihtimalini beraberinde getirmektedir. Ayrıca yönlendirme formlarının işlevsel olarak değerlendirilmediği de önemli bir bulgudur. Bunun sebepleri öğretmenlere sorulduğunda ise aşağıdaki sonuçlar ortaya çıkmıştır. 
Tablo 11: Yeterli ve Nitelikli Bilgi Toplanamama Nedenleri İle İlgili Öğretmen Görüşleri Frekans Dağılımı

\begin{tabular}{lc}
\hline İfadeler & $f$ \\
\hline Personel eksikliği & 42 \\
\hline Veri toplama yöntemlerinin bilinmemesi & 31 \\
\hline Diğer sebepler & 7 \\
\hline
\end{tabular}

Yeterli ve nitelikli bilgi toplanamama nedenlerinin başında personel eksikliği ile ilgili yöntemlerin bilinmemesi ve uygulanmaması gelmektedir. $\mathrm{Bu}$ da okullarda rehberlik ve yönlendirme konusunda daha çok uzman gerektiği ile sınıf ve branş öğretmenlerinin nitelikli rehberlik çalışmaları yapabilmek için veri toplama ve değerlendirme süreçleriyle ilgili uygulamalı hizmet içi eğitime ihtiyaç duyduklarını göstermektedir. Ayrıca "Okulunuzda öğrencilerin psikolojik ve sosyal özelliklerine ilişkin bilgi toplanıyor mu?" ve "Okulunuzda öğrencileri tanımaya yönelik ölçme araçları kullanılıyor mu?" ifadelerine ilişkin okulda bulunan rehber öğretmenlerin sayısı değişkenine göre yapılan ki-kare testi sonuçları aşağıldaki gibidir.

Tablo 12: Öğretmenlerin Öğrencilerin Psikolojik ve Sosyal Özelliklerine İlişkin Bilgi Toplama Konusundaki Görüşleri İle İlgili Ki-Kare Testi Sonuçları

\begin{tabular}{|c|c|c|c|c|c|c|c|c|}
\hline İfade & Değişken & & & & & & & $\begin{array}{l}\text { Ki- } \\
\text { kare }\end{array}$ \\
\hline \multirow{7}{*}{$\begin{array}{l}\text { Okulda } \\
\text { öğrencilerin } \\
\text { psikolojik } \\
\text { ve sosyal } \\
\text { özelliklerine } \\
\text { ilişkin bilgi } \\
\text { toplanması }\end{array}$} & & \multicolumn{2}{|c|}{ Evet } & \multicolumn{2}{|c|}{ Kismen } & \multicolumn{2}{|c|}{ Hayır } & \\
\hline & & $f$ & $\%$ & $f$ & $\%$ & $f$ & $\%$ & \\
\hline & Yok & 15 & 20 & 33 & 44 & 27 & 36 & \\
\hline & 1 öğrt. & 33 & 28 & 64 & 56 & 18 & 16 & \\
\hline & 2 öğrt. & 24 & 69 & 8 & 23 & 3 & 9 & 00. \\
\hline & 3 öğrt. & 16 & 30 & 28 & 52 & 10 & 19 & \\
\hline & 4 öğrt. & 2 & 40 & 1 & 20 & 2 & 40 & \\
\hline
\end{tabular}

Tablo 12'de görüldüğü üzere "Okulunuzda öğrencilerin psikolojik ve sosyal özelliklerine ilişkin bilgi toplanıyor mu?" ifadesi ile okuldaki rehber öğretmen sayısına ilişkin yapılan ki-kare testi sonucunda anlamlı bir ilişki olduğu görülmektedir $(p<.01)$. Buna göre okulda rehber öğretmen olması ve bu sayının artması ile öğrencilerin psikolojik ve sosyal özelliklerine ilişkin bilgi toplanması arasında doğrudan bir ilişki vardır. 
Tablo 13: Öğretmenlerin Okullarındaki Öğrencileri Tanımaya Yönelik Ölçme Araçları Kullanımı Hakkındaki Görüşleri İle İlgili Ki-kare Testi Sonuçları

\begin{tabular}{|c|c|c|c|c|c|c|c|c|}
\hline İfade & Değişken & & & & & & & $\begin{array}{l}\text { Ki- } \\
\text { kare }\end{array}$ \\
\hline \multirow{7}{*}{$\begin{array}{l}\text { Okulda } \\
\text { öğrencileri } \\
\text { tanımaya } \\
\text { yönelik } \\
\text { ölçme } \\
\text { araçları } \\
\text { kullanılması }\end{array}$} & \multirow[b]{3}{*}{ Yok } & \multicolumn{2}{|c|}{ Evet } & \multicolumn{2}{|c|}{ Kismen } & \multicolumn{2}{|c|}{ Hayır } & \\
\hline & & $f$ & $\%$ & $f$ & $\%$ & $f$ & $\%$ & \\
\hline & & 13 & 17 & 45 & 60 & 17 & 23 & \\
\hline & 1 öğrt. & 48 & 42 & 59 & 51 & 8 & 7 & \\
\hline & 2 öğrt. & 22 & 63 & 12 & 34 & 1 & 3 & .00 \\
\hline & 3 öğrt. & 12 & 22 & 26 & 48 & 16 & 30 & \\
\hline & 4 öğrt. & 1 & 20 & 4 & 80 & 0 & 0 & \\
\hline
\end{tabular}

Tablo 13'te sunulan veriler "Okulunuzda öğrencileri tanımaya yönelik ölçme araçları kullanılıyor mu?" ifadesi ile okuldaki rehber öğretmen sayısına ilişkin yapılan ki-kare testi sonucunda anlamlı bir ilişki olduğunu göstermektedir $(p<.01)$. Buna göre okulda rehberlik öğretmeninin olması rehberlik öğretmeni sayısının artması, öğrencileri tanımaya yönelik ölçme araçlarının daha fazla kullanılması sonucunu doğurmaktadır.

\section{4. Öğrencileri Yöneltme ve Kademeler Arası Geçiş Boyutu}

Tablo 14: Öğretmenlerin Öğrencileri Yöneltme ve Kademeler Arası Geçiş Konusundaki Görüşleri

\begin{tabular}{lcccc}
\hline İfade & Cevaplar & $f$ & \% \\
\hline İlköğretimde öğrencilere yönelik & Evet & 38 & 13.4 \\
\cline { 2 - 4 } $\begin{array}{l}\text { doldurulan yöneltme formlarının } \\
\text { işlevlerini yerine getirip getirmeme }\end{array}$ & Kısmen & 145 & $\mathbf{5 1 . 1}$ \\
\hline Bu formların ilköğretimden & Evet & 100 & 35.2 \\
\cline { 2 - 4 } $\begin{array}{l}\text { ortaöğretime geçişte ortaöğretim } \\
\text { kurumları tarafından dikkate alını } \\
\text { alınmaması }\end{array}$ & Kısmen & 107 & 12.7 \\
\hline $\begin{array}{l}\text { Ilköğretimden ortaöğretime geçiş } \\
\text { süresince yöneltme öneri kurulu } \\
\text { tarafından hazırlanan yöneltme }\end{array}$ & Evet & 140 & $\mathbf{4 9 . 3}$ \\
\cline { 2 - 4 } $\begin{array}{l}\text { öneri formunun aileler tarafından } \\
\text { dikkate alınıp alınmaması }\end{array}$ & Hayır & 135 & $\mathbf{4 7 . 5}$ \\
\hline
\end{tabular}


Öğrencilere yönelik yönlendirme ve kademeler arası geçişi boyutuyla ilgili öğretmenlere sorulan soruların cevapları incelendiğinde “öğrencilere yönelik doldurulan yöneltme formlarının işlevlerini yerine getirme konusunda öğretmenlerin $\% 51,1^{\prime} \mathrm{i}$ kısmen $\% 35,2^{\prime} \operatorname{sinin}$ ise hayır cevabını verdikleri belirlenmiştir. Bu da katılımcıların adı geçen formların doldurtulmasının pratikte bir karşılığının olmadığını düşündüklerini göstermektedir. $\mathrm{Bu}$ formların ilköğretimden ortaöğretime geçişte ortaöğretim kurumları tarafından dikkate alınıp alınmadığı sorulduğunda ise katılımcıların \%37'si kısmen, \%49,3'ü ise hayır cevabı vermiştir. Yani çalışmaya katılan öğretmenlerin yöneltme formlarının bir sonraki eğitim kademesinde herhangi bir biçimde kullanılmadığına inandıkları tespit edilmiştir. Bununla birlikte yöneltme öneri formunun aileler tarafından dikkate alınıp alınmadığı sorulduğunda ise öğretmenlerin \%47,5'i kısmen, $\% 44,7^{\prime}$ si ise hayır cevabını vermiştir. Dolayısıyla öğretmenlere göre yöneltme formları kademeler arası geçişte okullarda olduğu gibi aileler tarafından da verimli ve etkin bir biçimde değerlendirilmemektedir.

Tablo 15: Öğretmenlerin Öğrencilerin Üst Kademelere Geçişleri ve Sistemin Yapısı Hakkındaki Görüşleri

\begin{tabular}{|c|c|c|c|}
\hline İfade & Cevaplar & $f$ & $\%$ \\
\hline \multirow{3}{*}{$\begin{array}{l}\text { Öğrencilerinizin üst öğrenim } \\
\text { kademelerini seçerken bağımsız karar } \\
\text { verdikleri konusundaki düşünceler }\end{array}$} & Evet & 18 & 6.3 \\
\hline & Kismen & 118 & 41.5 \\
\hline & Hayır & 148 & 52.1 \\
\hline \multirow{3}{*}{$\begin{array}{l}\text { Yükseköğretime geçişte var olan } \\
\text { Ağırlıklı Ortaöğretim Başarı Puanının } \\
\text { yerleştirme puanına } \\
\text { arttırılması gerektiği konusundaki } \\
\text { düşünceler }\end{array}$} & Evet & 140 & 49.3 \\
\hline & Kismen & 87 & 30.6 \\
\hline & Hayır & 57 & 20.1 \\
\hline \multirow{3}{*}{$\begin{array}{l}\text { Ortaöğretim kurumlarına kaydolan } \\
\text { öğrencilerin bu öğretim kurumları } \\
\text { arasında daha rahat ve geniş } \\
\text { seçeneklerle yatay geçiş yapabilmeleri } \\
\text { gerektiği konusundaki düşünceler }\end{array}$} & Evet & 174 & 61.3 \\
\hline & Kismen & 78 & 27.5 \\
\hline & Hayır & 30 & 10.6 \\
\hline
\end{tabular}

Tablo 15'te görüldüğü üzere öğretmenlerin yalnızca $\% 6,3^{\prime} \ddot{u}$ öğrencilerin üst kademeye geçişlerinde bağımsız karar verdiklerini düşünmektedirler. Rehberlik ve yönlendirme sürecinde sürecin öznesi olan öğrencilerin kendi ilgi alanları ve tercihlerinin kendi bağımsız karar süreçlerine etki etmesi ileriki aşamalarda daha sağlıklı bireyler yetişmesi ve mesleki doyumu yüksek bireyler olması açısından önemlidir. Ailelerin 
yükseköğrenimi seçmede sürece çok müdahil olduklarını söylemek yanlış olmaz. Öğretmenler, yükseköğretime geçişte var olan A ğırlıklı Ortaöğretim Başarı Puanının yerleştirme puanına katkısının arttırılması gerektiğine $\% 49,3$ oranında evet cevabı vermişlerdir. Bu bulgu işığında seçme ve yerleştirmede sadece merkezi sınav odaklı olması yerine okul derslerinin de sürece olan katkısının arttırılmasının olumlu olacağı söylenebilir. Ayrıca öğretmenler \%61,3 evet oranıla öğrencilerin ortaöğretim kurumları arasında daha rahat geçiş yapabilmelerini istemektedirler. Sistemsel esnekliklerin bulunması ve daha özgür geçiş imkânları öğrencilerin kendilerini keşfetmelerine bağlı yaşadıkları değişimlerde ve değişen çevresel koşullarda bireylerin başarılarına daha büyük katkı yapacaktır.

Tablo 16: Zorunlu Eğitim Modeli Hakkındaki Görüşlerin Frekans Dağılımı

\begin{tabular}{lccc}
\hline İade & & $f$ & \% \\
\hline Zorunlu eğitimin hangi modele & $1+8+4$ & 17 & 6 \\
\cline { 2 - 4 } $\begin{array}{l}\text { göre daha etkili olacağ1 } \\
\text { konusundaki görüşler }\end{array}$ & $1+5+3+4$ & 98 & 34.5 \\
\cline { 2 - 4 } & $4+4+4$ & 63 & 22.2 \\
\cline { 2 - 4 } & $5+3+4$ & 64 & 22.5 \\
\cline { 2 - 4 } & $1+5+3+3$ & 38 & 13.4 \\
\cline { 2 - 4 } & Toplam & 280 & 100 \\
\hline
\end{tabular}

Uygulanan ankette katılımcilara sorulan sorulardan biri zorunlu eğitimde kademelerin nasıl bir modele göre düzenlenmesi gerektiği hakkındaki düşüncelerini belirlemeye yöneliktir. Tablo $16^{\prime}$ da sunulan verilere göre $1+5+3+4$ zorunlu eğitim modeli $\% 34,5$ ile öğretmenlerin en çok tercih ettiği modeldir. Buna göre anaokulu zorunlu olmall, 5. sinıf ilkokulda kalmalı ve lise eğitimi 4 yıl olarak devam etmelidir. Öğretmenler tarafından ikinci surada önerilen model olan $5+3+4$ 'in bir öncekinden tek farkı okul öncesi eğitimin zorunlu eğitime dâhil edilmemiş olmasıdır. Çarpıcı olan diğer bir sonuç ise 8 yıllık eğitim sisteminin üzerine 4 yıl lise ve öncesine 1 yıl anaokulu eklenerek oluşturulmuş modelin katılımcıların yalnızca \%6'sı tarafından önerilmesidir. Bu da son yasal düzenlemeyle yürürlükten 8 yılllk zorunlu ve kesintisiz eğitim modeline duyulan hoşnutsuzluğun bir göstergesi olarak kabul edilebilir.

Kademeler arası geçişle ilgili olarak anketin son bölümünde öğretmenlere "Kademeler arası geçiş dikkate alındığında 4+4+4 uygulaması hakkında ne düşünüyorsunuz?" sorusu yöneltilmiştir. Elde edilen bulgular ve çıkarımlar dört kategoride toplanmıştır bunlar sırasıyla olumlu, olumlu 
ama eksiklikleri var, olumsuz ve kararsız kategorileridir. Aşağıdaki tabloda sorulara verilen cevaplar kodlar şeklinde sunulmuştur.

Tablo 17: 4+4+4 Uygulaması Hakkındaki Açık Uçlu Soruda Bildirilen Görüşlerin Dağılımı

\begin{tabular}{cccc}
\hline Olumlu & $\begin{array}{c}\text { Olumlu- } \\
\text { Eksik/Hatalı }\end{array}$ & Olumsuz & Kararsız \\
\hline 21 & 89 & 167 & 7 \\
\hline
\end{tabular}

Sistemi olumlu bulan bir katılımc1, "Yaş gruplarının yakın olduğ $u$ eğitim olması sebebiyle olumlu buluyorum" (235) şeklinde görüşünü ifade etmiştir. Uygulamayı olumlu bulan ama eksiklikleri olduğunu belirten katılımcılardan ikisi bu eksikliklerin altyapı oluşturulmadan yeni sisteme geçilmesinden kaynaklandığını aşağıda sunulduğu biçimde ifade etmişlerdir:

"Faydalı olabilir, fakat altyapı yetersizliği ve fazla araştırılmadan bu işin başındaki öğretmenlerle tartışılmadan geçilmesi olumsuzlukları da birlikte getirdi. Öğretmenlerin bu sisteme alısması için yeterli zaman verilmedi. Her sene sistem değişikliği ile yıpranan öğretmenler bir defa daha yıprandı (243).

“Geçiş sistemi iyi niyetli ama her zamanki gibi altyapr çok zayıf. Bu yıl Din Kültürü Dersi'nin sinava dâhil edilmesi yanlış. Öğrencilerin dini değerlere karşı olumsuz tutumlar geliştirmesine sebep oluyor. Sinavlar 4 ana dersten olmall, Matematik, Fen, Türkçe ve Sosyal Bilgiler" (238).

Uygulamayı olumlu bulan ama eksiklikleri olduğunu belirten katılımcılar ayrıca, okul öncesi eğitimin zorunlu olması gerektiğini, okula başlama yaşının önce 66 aya düşürülüp sonra bu sınırın esnetilmesinin uygun bir yaklaşım olmadığını, yeni sistemle birlikte 5. sınıfların ortaokula geçişinin sıkıntılar doğuracağını, eğitim program ve ortamlarına daha fazla sosyal ve sportif aktivitenin entegre edilmesi gerektiğini ve daha etkin yönlendirme hizmetlerinin faydalı olacağını düşünmektedirler.

Sistemi olumsuz bulan katılımcıların bir kısmı bunun nedeninin altyapı oluşturulmadan yeni sisteme geçilmesi olduğunu ifade ederken diğer bir grup katılımcı ise yapılan düzenlemenin arka plandaki başlıca nedenin siyasi olduğunu düşündüklerini ifade etmişlerdir. Bu gruptaki katılımcllardan bir görüşlerini şöyle dile getirmiştir:

"Eğitim sistemi yap-boz tahtasına dönüştürüldü, okullaşmanın az olması yönlendirmeler yanlış yapılmakta ve sınıf mevcutları 
artmaktadır, 4+4+4 imam hatipler için yapılmıştır. Çağdaş, bilimsel ve mesleki eğitim göz ardı edilmektedir" (55).

$4+4+4$ Sistemini olumsuz olarak değerlendiren öğretmenler de bu görüşlerinin gerekçesi olarak ayrıca okula başlama yaşının uygun olmamasını, 5. sınıfların ortaokula geçişinin sıkıntılar doğurmasını ve uygulamada yaşanan aksaklıkları göstermişlerdir. Bir grup katılımcı ise bu sistemin en sorunlu tarafının etraflıca araştırılıp incelenmeden ve çeşitli paydaşların görüş ve önerileri dikkate alınmadan uygulamaya konulması olduğunu belirtmiştir. Bu gruptaki öğretmenlerden birinin yorumu şöyledir:

"4+4+4 eğitim sistemi pilot uygulaması yapilmadan, olumlu ve olumsuz yönleri saptanmadan uygulamaya konulmuş bir sistem. Öğretmenleri karar mekanizmalarına dâhil etmiyorlar. Tepeden dayatma sistemler aşağıda önyargıya sebep oluyor. Sanki uygulayacak olanlar öğretmenler değilmiş gibi öğretmenler sürece uzak tutuluyor. Sistemin çok verimli olmadığın düşünüyorum; özellikle okula erken başlama ve 5. simflarm ortaokula dâhil edilmesi en büyük hatalardan bazıları. Bu konuda çok derin araştırmalar yapılmalı ve öyle karar verilmeliydi, akşamdan sabah böyle şeyler değiştirilemez" (284)

Sistemin olumlu ya da olumsuz olduğunu beyan etmeyen katılımcılar ise temkinli davranarak uygulama hakkında değerlendirme yapabilmek ve görüş beyan etmek için belirli bir süre beklenmesi gerektiğini düşündüklerini ifade etmişlerdir.

\subsection{Yeni Sınav Sistemi Boyutu}

Yeni sınav sistemi ile ilgili sorulan sorular ışı̆̆ında, öğretmenlerin yeni orta öğretime geçiş sistemini ve yeni sınav sistemini uygun bulmadıkları ortaya çıkmaktadır. Ayrıca yeni sınav sisteminin uygun bulunup bulunmadığı ile ilgili sorulan soruya verilen cevaplar aşağıdaki gibidir. 
Tablo 18: Temel Eğitimden Ortaöğretime Geçiş Sistemi (TEOGS) Konusundaki Öğretmen Görüşleri

\begin{tabular}{|c|c|c|c|}
\hline İfade & Cevaplar & $f$ & $\%$ \\
\hline \multirow{3}{*}{$\begin{array}{l}\text { Yeni ortaöğretime geçiş sistemi } \\
\text { (TEOGS) ile getirilen uygulamayı } \\
\text { doğru bulup bulmama ile ilgili } \\
\text { görüşler }\end{array}$} & Evet & 47 & 16.5 \\
\hline & Kismen & 134 & 47.2 \\
\hline & Hayır & 100 & 35.2 \\
\hline \multirow{3}{*}{$\begin{array}{l}\text { Yeni uygulamadaki sınav sistemini } \\
\text { (altı dersin merkezi sınavı) uygun } \\
\text { bulup bulmama ile ilgili görüşler }\end{array}$} & Evet & 70 & 24.6 \\
\hline & Kismen & 105 & 37.0 \\
\hline & Hayır & 108 & 38.0 \\
\hline
\end{tabular}

Tabloya göre öğretmenlerin \%47,2'si yeni Ortaöğretime Geçiş Sistemini kısmen doğru, \%35,2'si ise tamamiyla uygun olmayan bir uygulama olarak değerlendirmektedir. Yeni geçiş sisteminde 6 dersin merkezi sınava dâhil edilmesi hususunu ise öğretmenlerin \%37'si kısmen uygun, \%38'i de uygunsuz bulmaktadır. Dolayısıyla katılımcıların TEOGS ve içerdiği sınavları tasvip etmedikleri ve uygulamada bir fark oluşturabileceğini düşünmedikleri söylenebilir.

Çalışma kapsamında öğretmenlere “Türkiye' de ilköğretim (İlk Okul, Ortaokul) ve orta öğretim (Lise ve Dengi Okullar) sistem bütünlüğü içinde değerlendirildiğinde ideal bir kademeler arası geçiş sisteminin özellikleri neler olmalıdır?" sorusu sorulmuş ve verdikleri cevaplar incelenerek aşağıda sunulmuştur. Elde edilen bulgulara göre öğretmenler, eğitim sistemindeki kademe yapısının 4+4+4 şeklinde değil 1998 yılı öncesindeki uygulamayı anımsatan bir biçimde 5+3+4 olarak düzenlenmesi, kademeler arası geçişte daha kapsayıcı, adil ve eşitlikçe sınav sistemlerinin uygulanması, okul öncesi eğitimin de mutlaka zorunlu eğitime dâhil edilmesi, bütün eğitim kademelerinde okutulacak olan derslerin, ders saatlerinin ve öğretim programlarının oluşturulmasında öğrenci, öğretmen ve veli gibi paydaşların katılım ve katkılarının esas alınması, öğrencilerin ilgi ve yetenekleri doğrultusunda ortaokula yönlendirilmesi ve ortaokullardaki branş veya mesleğe yönelik eğitim faaliyetlerinin çeşitlendirilmesi gibi öneriler dile getirmişlerdir.

Çalışmaya katılan öğretmenlerden birinin kademeler arası geçişe esas teşkil eden sınavlar hakkındaki önerisi şöyledir: "Okul müfredatını kapsayan, öğrencilerin bilgilerini yoklayıp ayırt edici bir sinav olması gerektiğini ve bireysel farklilklarn göz önünde bulundurulması gerektiğini düşünüyorum (203). Ortaokullardaki branş veya mesleğe yönelik eğitim faaliyetlerinin çeşitlendirilmesini öneren katılımcılardan biri ise düşüncelerini aşağıdaki gibi ifade etmiştir: 
"5+3+4 sistemi olmall. Her çeşit meslek lisesinin ortaokul bölümü olmalı (imam hatip gibi). Ana sinıfı dâhil 6 yıl çocuğun bedensel, ruhsal ve beceri gelişimleri ile akademik zekâlarını ölçen să̆lam ve sağlıkl ölçüm parametreleri kullanılarak her gün gözlem yapılmal ve hangi ortaokul bölümüne gidebileceğgi objektif olarak raporlanmalıdır. Zaman zaman gözlemler ile ilgili olarak veli ve okul idaresi ile görüşmeler yapılmalıdır" (255).

\section{Tartışma ve Sonuç}

Araştırmada elde edilen bulgular yukarıda bahsedilen 5 alt boyut ışığında anlamlı bulunan sonuçlar ve bu sonuçlarla ilgili çalışmalarla birlikte aşağıda sıralanmıştır;

Rehberlik ve yönlendirme boyutunda okullardaki rehberlik hizmetlerinin yeterli bulunmadığı bunun sebebi olarak da okullarında rehber öğretmen olmaması veya olsa da sayıca yetersiz kalmaları sonucuna ulaşılmıştır. Dolayısıyla yapılması gereken okullarımızdaki nitelikli rehber öğretmen sayısının artırılarak bu hizmetlerin layıkıyla yerine getirilmesinin sağlanmasıdır. Uluğ da (1999'dan akt. Tarlakazan, 2013: 7) benzer bir biçimde eğitim-öğretim hizmetlerinin amacına ulaşmasının öğrencilerin kapasite, ilgi ve yetenekleri doğrultusunda eğitim görmelerine bağlı olduğunu, bunu sağlamanın da ancak yeterli ve verimli rehberlik ve yönlendirme çalışmalarıyla mümkün olacağını belirtmiştir.

Çalışmanın bir diğer bulgusu ise öğretmenlerin okullarındaki mesleki rehberlik ve yönlendirme hizmetlerini yeterli bulmadıklarını göstermektedir. Bunun nedeni olarak ise öğrencilerin ilgi ve yetenek alanlarının belirlenmesine yönelik eksiklikler ve öğrencilerin hobiler edinebilecek ya da hobilerini sürdürebilecekleri fiziksel koşulların yetersizliğini gösterilmiştir. Yılmaz'ın (2004) çalışmasında da öğrencilerin yetenek, ilgi, kişilik özellikleri ve diğer yeterlilikleri göz önüne alınmadan bir sonraki eğitim kademesine yönlendirilip yerleştirilmelerinin ortaöğretim kurumlarındaki başarısızlıkların başlıca nedenlerinden bir olduğu sonucuna varılmıştır. Yılmaz'ın çalışmasına paralel bir biçimde bu araştırma sonuçları da mesleki yönlendirmenin mümkün olduğunca erken yaşta başlaması gerektiğine ve hali hazırda okullarımızda uygulanan yöneltme formlarının işe yaramadığına, bir sonraki kademede dikkate alınmadığına ve özenle doldurulmadığını işaret etmektedir.

Araştırmada ulaşılan bir diğer bulgu katılımcıların hali hazırdaki rehberlik ve mesleki yönlendirme çalışmalarını yeterli bulmamakla birlikte 
4+4+4 sisteminin yönlendirme ve dolayısıyla mesleki eğitim için bir fırsat olabileceğini düşündüklerini göstermektedir. Bu bulgu da Şahin ve Fındık (2008), Uçar ve Özerbaş (2013) ile Tarlakazan' in (2013) çalışmalarında elde edilen sonuçlarla uyumluluk göstermektedir.

Çalışmanın psikolojik ve sosyal özellikler boyutu ile ilgili olarak elde edilen bulgulara göre öğretmenler, okullarında gerçekleştirilen öğrencilerin psikolojik ve sosyal özelliklerini belirleme ve bunlara uygun rehberlik ve yönlendirme faaliyetleri sağlama faaliyetlerini yetersiz bulmaktadırlar. Ayrıca katılımcılar, öğrenciler hakkında yeterli ve nitelikli bilgi toplanamama nedeni olarak en fazla personel eksikliğini göstermişlerdir. Bu bulgulara göre okullardaki rehberlik ve yönlendirme hizmetlerinde öğrencilerin sosyal özellikleri çok iyi değerlendirilmemekte ve ayrıca üst kademelere geçişte de sosyal ve psikolojik özelliklerin etkisi dikkate alınmamaktadır.

Eğitim kademelerinin oluşturulmasında esas alınan $4+4+4$ sistemi hakkında öğretmenlerin çok büyük bir kısmı olumsuz görüşe sahiptir. Bu olumsuz görüşlerin nedenleri ise belirli bir altyapı oluşturulmadan ve eğitim paydaşlarının görüş ve önerileri dikkate alınmadan uygulamanın başlatılmasıdır. Çalışma katılımcılarının önemli bir kısmı zorunlu eğitimin 12 yıla çıkarılmasını ve ilköğretimin ilkokul ve ortaokul olarak yeniden yapılandırılmasını uygun görürken kademelerin düzenlenmesi noktasında $5+3+4$ 'ün esas alınmasını önermişlerdir. Ortaokul kademesinde mesleki eğitimin çeşitlendirilmesinin faydalı olacağı da çalışma kapsamında ulaşılan bir başka önemli bulgudur.

Katılımcılar ayrıca, yeni ortaöğretime geçiş sınav sistemini (TEOGS) kısmen uygun bulurken 6 dersi kapsayan merkezi sinavları ise uygun bulmamıştır. $\mathrm{Bu}$ hususta katılımcılar okul programlarını kapsayan, öğrencilerin bilgilerini yoklayıp ayırt edebilen ve bireysel farklılıkları dikkate alan bir sınav sistemini gerekli gördüklerini ve bu amaca yönelik çalışmalar yapılmasını önermişlerdir.

\section{Kaynakça}

Argon, T., \& Soysal, A. (2012). Seviye belirleme sınavına yönelik öğretmen ve öğrenci görüşleri. International Journal of Human Sciences [Online] ISSN:1303-5134, 9(2), 446-474.

Aşık, T. (2008). İlköğretimde yöneltme öneri formu uygulamasının öğrencilerin okul ve alan seçimlerine etkilerinin belirlenmesi. Çukurova Üniversitesi Sosyal Bilimler Enstitüsü Eğitim Bilimleri Anabilim Dalı Yayımlanmamış Yüksek Lisans Tezi (119 Sayfa). 
Arı, E., \& Vatansever, F. (2009). Bulanık mantık tabanlı mesleki yönlendirme. 5. Uluslar arası Illeri Teknolojiler Sempozyumu (IATS'09), 13-15 Mayıs 2009, Karabük., 1-3.

Arslan, M. (2004). Eğitim sistemimizin kapanmayan yarası - Yükseköğretime geçiş. Erciyes Üniversitesi Sosyal Bilimler Enstitüsü Dergisi (16), 37-51.

Doğan, H. (1997). Mesleki teknik eğitimin yeniden yapılandırılması. Ankara Üniversitesi Ĕgitim Bilimleri Fakültesi Dergisi , 30(1), 1-26.

Humphreys, A. J., Traxlar, A. E., \& North, R. D. (1967). Guidance services. Chicago: Science Research Associates.

Karadeniz, C. B. (2012). Öğretmenlerin 4+4+4 zorunlu eğitim sistemine ilişkin görüssleri. Eğitim Bilim Toplum Dergisi, 10(40), 34-53.

Külekçi, E. (2013, Mayıs). 4+4+4 Eğitim sistemi kapsamında birleştirilmiş sınıf uygulamasına ilişkin öğretmen görüşlerinin değerlendirilmesi. Eğitim ve Öğretim Araştırmaları Dergisi ISSN:2146-9199, 2(2), 369-377.

MEB. (1973). Milli Eğitim Bakanlığı 1739 Sayılı Milli Ĕ̆itim Temel Kanunu.

(Kabul Tarihi 14.06.1973)

http://personel.meb.gov.tr/daireler/mevzuat/mevzuatlar/milli_egiti m_temel_kanunu_1739.pdf

MEB. (1999). MEB Tebliğler Dergisi. 1999. Sayı : 2504.

Memişoğlu, S. P., \& İsmetoğlu, M. (2013, Mayıs). Zorunlu eğitimde 4+4+4 uygulamasına ilişkin okul yöneticilerinin görüşleri . Eğitim ve Öğretim Araştırmaları Dergisi ISSN:2146-9199, 2(2), 14-25.

Özoğlu, S. Ç. (1981). Eğitimde rehberlik ve psikolojik danı̧ma. Ankara: Ankara Üniversitesi Eğitim Fakültesi Yayınları No:203 3. Baskı; ISBN: 975482-403-7.

Şahin, İ., \& Fındık, T. (2008, Aralık). Türkiye'de mesleki ve teknik eğitim: mevcut durum, sorunlar ve çözüm önerileri. Türkiye Sosyal Araştırmalar Dergisi, 12(3).

Tarlakazan, B. (2013, Eylül). Osmanlı'dan günümüze mesleki teknik eğitimin tarihsel gelişimi ve günümüz mesleki teknik eğitimine yönelik öneriler. 2(2), 71-78. Mesleki Bilimler Dergisi ISSN:2146-7420.

Uçar, C., \& Özerbaş, M. A. (2013, Mayıs). Mesleki ve teknik eğitimin dünyadaki ve Türkiye'deki konumu. 2(2). Eğitim ve Öğretim Araştırmaları Dergisi ISSN:2146-9199.

Uluğ, F. (1999). Eğitimde grup süreçleri. Ankara: TODAİE Yayınları. 
Sosyal Bilimler Dergisi 235

Yılmaz, M. T. (2004, Temmuz 6-9). Okullardaki mesleki rehberlik uygulamalarında iki temel sorun. Malatya: XIII. Eğitim Bilimleri Kurultayi.

Yurdakul, S. (2009, Haziran). Kademeler arası geçiş ve yönlendirme araştırması. EBSAM Araştırmaları 1; Ĕ̆itimciler Birliği Sendikası Yayınları: 38 Araştırma Dizisi:7 1.Baskı, 135-146. 